\title{
Efektifitas Fungsi Badan Pemusyawaratan Desa (BPD) dalam realisasi Dana Desa (DD) dan Alokasi Dana Desa di Kabupaten Sumenep.
}

\author{
Oleh: \\ Roos Yuliastina \\ Ach. Andiriyanto \\ E-mail: yuliastina07@gmail.com \& aryauri@gmail.com \\ Dosen Program Studi Administrasi Negara Fakultas IImu Sosial dan IImu Politik \\ Universitas Wiraraja
}

\begin{abstract}
Abstrak
Pada tahun 2016 rata -rata desa di Kabupaten Sumenep mendapatkan dana sebanyak 900 juta. Penggunaan DD dan ADD dibutuhkan peranan Badan Permusyawaratan Desa (BPD) sebagai pelaksanan pemerintahan yang memiliki hak dan fungsi strategis dalam mendorong efektifitas penggunaan DD dan ADD. Penelitian ini bertujuan untuk menganalisa dan menggambarkan Efektifitas Fungsi Badan Pemusyawaratan Desa (BPD) dalam realisasi Dana Desa (DD) dan Alokasi Dana Desa di Kabupaten Sumenep. Lokus penelitian yaitu di Kecamatan Batang - batang meliputi desa Banuaju barat dan Banuaju timur, dan di Kecamatan Gapura meliputi desa Gerujugan dan Kecamatan Dungkek di desa Jadung.

Hasil penelitian ini menunjukkan jika fungsi BPD menjadi efektif jika dikaitkan dengan kegiatan mengayomi dan menampung aspirasi masyarakat di tingkat dusun dan desa dari segi pembangunan, selain itu fungsi BPD dalam meyalurkan usulan warga terkait penggunaan DD dan ADD telah menunjukkan arah perubahan kebijakan pemerintah desa yang pada periode sebelumnya bersifat topdown saat ini mulai bergeser ke arah bottom-up. Fungsi BPD juga menjadi efektif jika dihubungkan dengan kegiatan memberikan pemahaman ke pada masyarakat terkait berapa anggaran yang diterima desa, berapa ususlan yang akan disampaikan pada kepala desa dan apa yang menjadi alasan utama usulan daari warga ditolak. Dengan kata lain, peran BPD sampai saat ini di kabupaten Sumenep lemah atau tidak efektif pada sisi pengawasan dan evaluasi pengalokasian DD dan ADD di desa masing - masing
\end{abstract}

Kata kunci: Efektifitas,BPD, Dana Desa (DD),dan Alokasi Dana Desa (ADD) 


\section{A. Pendahuluan}

Pemerataan pembangunan dengan memperkuat Perdesaan merupakan salah satu program utama dalam pemerintahan kabinet kerja Jokowi-JK, sebagaimana yang termuat dalam Nawa Cita poin ketiga "membangun Indonesia dari pinggiran dengan memperkuat Daerah-daerah dan desa dalam kerangka negara kesatuan. Komitmen itu diwujudkan dengan adanya Undang-Undang Nomor 6 Tahun 2014 tentang Desa (UU RI No.6 Tahun 2014, dalam situs http://www.setneg.go.id. Diakses pada 15 februari 2017) , kemudian Peraturan Pemerintah Nomor 43 tahun 2014 tentang perlaksanaan UU No 6 2014, Peraturan pemerintah No 47 tahun 2015 tentang perubahan PP No 43 tahun 2014, dan Peraturan pemerintah No 60 tahun 2014 tentang Dana Desa bersumber dari APBN yang diperbaharui dengan Peraturan Pemerintah No 22 tahun 2015 tentang perubahan PP nomor 60 tahun 2014.Pemerintah telah membuat role of the policy sebagai komitmen dalam pemerataan pembangunan melalui pinggiran dan pedesaan.

Selaras dengan role of law yang dibuat oleh pemerintah dalam membangun pinggiran dengan memperkuat pedesan dapat pula dilihat dari kebijakan alokasi Dana Desa (DD) yang bersumber dari APBN sebagai belanja pemerintah pusat dengan mengefektifkan program yang berbasis Desa secara merata dan berkeadilan, sebagaimana UU No 6 tahun 2014 pasal 72 ayat (2). Dana Desa yang bersumber dari APBN dapat digunakan untuk mendanai penyelenggaraan pemerintahan, pelaksanaan pembangunan, pembinaan kemasyarakatan dan pemberdayaan masyarakat (Kebijakan Dalam Anggaran Dalam situs http://www.masawah.desa.id. Diakses pada, 15 Februari 2017) . Melalui Dana Desa potensi pembangunan akan semakin rata serta kesejahteraan akan semakin meningkat, DD juga mendorong pada kemandirian Desa dalam mengelola APBDes dan mengembangkan potensi yang ada di Desa.

Adapun rincian dari peningkatan DD sebagaimana dilaporkan oleh Sekretariat Kabinet RI, yaitu pada tahun 2015 sebesar Rp. 20,7 triliun, meningkat dua kali lipat pada tahun 2016 sebesar Rp. 46,9 triliun. Tiap desa akan mengelola uang secara mandiri kisaran 500-800 juta. Pada tahun 2017 dimungkinkan sesuai dengan rancangan akan naik menjadi 81,1 triliun, masyarakat desa sudah bisa mengelola DD lebih dari Rp. 1 miliar per desa (Dana Desa Pemerintaha Jokowi Wujudkan Kedaulatan Desa, dalam situs http://setkab.go.id/. dikases 15 februari 2017). bahkan sesuai dengan roadmap yang alokasi DD pada tahun 2018-2019 rata-rata desa akan mendapatkan 2.197,1 miliar sampai 2.368,6 miliar (Kebijakan Pengalokasian dan penyaluran Dana Desa tahun 2017, dalam situs www.djpk.depkeu.go.id. Diakses 17 februari 2017).

Selain DD terdapat pulan Alokasi Dana Desa (ADD) yang diambil dari APBD tiap-tiap kabupaten. Sehingga besaran ADD berbeda-beda antar kabupaten. ADD juga diarahkan pada pembangunan dan pemberdayaan desa guna mendorong pada kemandirian desa. untuk wilayah kabupaten Sumenep, pada tahun 2015 anggaran ADD mencapai Rp.115.364.560.000 sedangkan anggaran ADD tahun 2016 mencapai Rp.123.956.150.000 untuk 330 Desa yang meliputi daratan dan kepulaian (Kontrol DD dan ADD, DPRD Sumenep Lakukan Sejumlah Sidak, dalam situs http://m.timesindonesia.co.id. Diakses 16 Februari 2017).

Melakukan pembangunan perdesaan dengan pendekatan partisipasi masyarakat tidak mudah dilakukan. Keinginan masyarakat yang beragam terkadang tidak rasional untuk dijadikan program pembangunan oleh pemerintah Desa. Keinginan dan kebutuhan masyarakat harus mempertimbangkan potensi- 
potensi dan sumber daya di desa serta peluang pasar jika berkaitan dengan pemberdayaan di bidang ekonomi masyarakat. Maka tidak jarang seperti di beberapa daerah termasuk di kabupaten Sumenep ada keseragaman pembangun antar desa tanpa melalui analisis kebutuhan dan manfaat untuk masyarakat setempat, seperti halnya pembang unan pintu gerbang Desa, pembangunan sanitasi dan pembangunan-pembagunan lainnya, selain itu realisasi DD dan ADD di Kabupaten Sumenep lamban (DPRD Sumenep Soroti Realisasi Dana $A D D$ dan DD Lamban, dalam situs http://.newsmadura.com. Diakses 20 Februari 2017) . Pendekatan partisipatoris perlu kecakapan untuk melihat potensi dan peluang desa.

sebagai skala prioritas dalam pembangunan. Pemerintah Desa perlu melakukan pendekatan yang intensif terhadap masyarakat sebelum mengambil kebijakan dalam pembangunan. Maka dalam Kepala desa tidak boleh merumuskan sendiri realisasi DD guna mencapai tujuan kemandirian Desa. Untuk meningkatkan realisasi DD dan ADD agar sesuai dengan kebutuhan rakyat tidak hanya menggantungkan pada kemampuan pemerintah Desa. Dalam hal ini, perlu dioptimalkan peranan BPD yang memiliki hak dan fungsi sangat strategis dalam mendorong peningkatan efektifitas dan efisiensi realitasi DD dan ADD.

Berdasarkan latar belakang tersebut, penelitian ini ingin mengkaji lebih jauh apakah peran BPD dapat meningkatkan efektifitas realisas Dana Desa dan alokasi Dana Desa dari empat desa yang dipilih dalam penelitian ini. Dalam setiap penggunaan anggaran maupun rencana program, efektifitas menjadi konsep penting agar rencana dapat berjalan sesuai dengan target dan tujuan yang ingin dicapai. Dengan semakin meningkatnya anggaran DD dan ADD dalam program pembangun Desa diperlukan juga peningkatan efektifitas penggunaan DD dan ADD agar supaya kemandirian Desa dan kesejahteraan masyarakat terwujudkan secara efektif dan efisien.

Dalam pada itu, efektifitas dimaknai sebagai sarana untuk mencapai kemampuan agar dapat menyelesaikan tugas-tugas yang diserahkan sebagai tanggung jawabnya dengan tepat sasaran dan waktu (Widodo, 2005. "Pembaharuan Otonomi Daerah", Yogyakarta, APMD Press, hal 2). Efektifitas merujuk pada hasil yang dicapai (Sondang, 2001:24), berkaitan antara keluaran dari program dan tanggung jawab dengan sasaran yang mesti dicapai, semakin besar kontribusi daripada keluaran yang dihasilkan terhadap nilai pencapaian (Supriyono, $2000: 29$ ).

Tingkat efektivitas juga dapat diukur dengan membandingkan antara rencana yang telah ditentukan dengan hasil nyata yang telah diwujudkan. Namun, jika usaha atau hasil pekerjaan dan tindakan yang dilakukan tidak tepat sehingga menyebabkan tujuan tidak tercapai atau sasaran yang diharapkan, maka hal itu dikatakan tidak efektif. Adapun kriteria atau ukuran mengenai pencapaian tujuan efektif atau tidak, sebagaimana dikemukakan oleh S.P. Siagian (1978:77), yaitu:

a) Kejelasan tujuan yang hendak dicapai, hal ini dimaksdukan supaya karyawan dalam pelaksanaan tugas mencapai sasaran yang terarah dan tujuan organisasi dapat tercapai.

b) Kejelasan strategi pencapaian tujuan, telah diketahui bahwa strategi adalah "pada jalan" yang diikuti dalam melakukan berbagai upaya dalam mencapai sasaran-sasaran yang ditentukan agar para implementer tidak tersesat dalam pencapaian tujuan organisasi. 
c) Proses analisis dan perumusan kebijakan yang mantap, berkaitan dengan tujuan yang hendak dicapai dan strategi yang telah ditetapkan artinya kebijakan harus mampu menjembatani tujuan- tujuan dengan usahausaha pelaksanaan kegiatan operasional.

d) Perencanaan yang matang, pada hakekatnya berarti memutuskan sekarang apa yang dikerjakan oleh organisasi dimasa depan.

e) Penyusunan program yang tepat suatu rencana yang baik masih perlu dijabarkan dalam program-program pelaksanaan yang tepat sebab apabila tidak, para pelaksana akan kurang memiliki pedoman bertindak dan bekerja.

f) Tersedianya sarana dan prasarana kerja, salah satu indikator efektivitas organisasi adalah kemamapuan bekerja secara produktif. Dengan sarana dan prasarana yang tersedia dan mungkin disediakan oleh organisasi.

g) Pelaksanaan yang efektif dan efisien, bagaimanapun baiknya suatu program apabila tidak dilaksanakan secara efektif dan efisien maka organisasi tersebut tidak akan mencapai sasarannya, karena dengan pelaksanaan organisasi semakin didekatkan pada tujuannya.

h) Sistem pengawasan dan pengendalian yang bersifat mendidik mengingat sifat manusia yang tidak sempurna maka efektivitas organisasi menuntut terdapatnya sistem pengawasan dan pengendalian.

Selain ke kedelaan kriteria efektifitas diatas sebagai tolak ukur yang dapat di gunakan dalam menjalankan fungsi BPD di kabupaten Sumenep, hasil dari penelitian ini kiranya dapat menjadi bahan pertimbangan dan evaluasi terait kegiatan dan fungsi BPD di tingkat desa dalam menciptakan tata pemerintahan yang baik.

Lokasi penelitian diplih secara acak atau random, karena pada dasarnya penelitian ini ingin mengatahui bagaimana fungsi BPD dan apakah kehadiran BPD dapat meningkatkan efesiensi penggunaan DD dan ADD di Kabupaten Sumenep, karena banyak kasus yang dilapangan yang menunjukkan jika pengelokasian DD dan ADD cenderung seragam antara desa satu dengan yang lainya, dan selain itu pengelokasian DD dan ADD lebih terfokus pada pembangunan infrastruktur dari pada pembangunan non-infrastruktur. Sehingga dengan pengambilan lokasi penelitian secara acara melalui perwakilan empat desa ini diharapkan dapat menjawab tujuan penelitian dengan gamblang.

Adapun tujuan penelitian ini ingin mengetahui Hak dan Fungsi BPD sebagai lembaga pemerintahan Desa di Kabupaten Sumenep dan Untuk menjelaskan fungsi BPD dalam meningkatkan efektifitas pengunaan DD dan ADD di Kabupaten Sumenep. Lokasi penelitian ini diambil di tiga kecamatan yang bereda, dari ketiga kecamatan ini lokus penelitan di ambil pada empat desa yang berlainan. Yaitu di Kecamatan Batang - batang meliputi desa Banuaju barat dan Banuaju timur, dan di Kecamatan Gapura meliputi desa Gerujugan dan Kecamatan Dungkek di desa Jadung.

\section{B. Metode Penelitian}

Metode penelitian yang akan digunakan adalah deskriptif kualitatif. Penelitian desktiptif merupakan penelitian yang berupaya menggambarkan dan mengungkapkan masalah dan keadaan yang terjadi (Moleong, 2004:11). Sedangkan, kualitatif merupakan metode penelitian untuk mengekplorasi dan memahami makna yang -oleh sejumlah individu atau kelompok orang- dianggap berasal dari masalah sosial atau kemanusian. Proses penelitian kualitatif yang akan digunakan melalu upaya-upaya diantaranya; mengajukan pertanyaanpertanyaan dan prosedur- prosedur, mengumpulkan data yang spesifik dari partisipan, menganalisis data, dan menafsirkan makna data (Creswell, 2013:4-5). 
Dalam memperoleh data, terdapat tekhnik pengumpulan data yang diambil, yakni pengumpulan data primer dan pengumpulan data skunder: (1) Data Primer, Sumber data primer digunakan sebagai sumber data pertama. Dalam penelitian ini, data primernya adalah sumber informasi yang diperoleh dari kepela desa masing - masing desa yang dituju (kepala desa Banuaju barat dan Banuaju timur, kepala desa Grujungan dan kepala desa Jadung). Dan narasumber primer lainnya dalah ketua Badan pemusyawarat desa (BPD) keempat desa tersebut, namun tidak menutup kemungkinan melakukan wawancara kepada narasumber pendukung seperti anggota BPD dan warga setempat. Sumber data primer yang dimaksud, yaitu mengumpulkan data-data dari hasil wawancara mendalam (depth interviews) dan observasi.

(2) Data Skunder, peneliti menggunakan data sekunder dalam pengumpulan datanya, karena data skunder dapat digunakan untuk melengkapi data primer dalam mengumpulkan data, hal ini di karenakan keterbatasan data primer. Misalnya, dokumen-dokumen tertulis susunan anggota BPD, kemudian berita dari media cetak maupun media elektronik (internet), dan penelitian terdahulu yang membahas Dana Desa dan Alokasi Dana Desa di keempat desa tersebut.

Peneliti menggunakan teknik analisis data kualitatif. Peneliti menggunakan teknik ini karena data yang terkumpul berupa data-data kualitatif berupa katakata, kalimat atau narasi. Dapat dikatakan bahwa peneliti memulai menganalisis data yang diperoleh sejak hari pertama menapakkan kaki penelitiannya. Menurut Creswell (2013: 274) menjelaskan tahapan-tahapan analisis data sebagai berikut:

1. Mengolah dan mempersiapkan data untuk dianalisis. Langkah ini melibatkan transkip wawancara, mengtik data lapangan, atau memilih dan memilah dan menyusun data ke dalam jenis - jenis yang berbeda berdasarkan pada sumber informasi

2. Membaca keseluruhan data. Pada tahap ini membangun general sense atas informasi yang diperoleh dan merefleksikan maknanya secara keseluruhan

3. Menganalisis data dengan meng-coding data. Coding merupakan proses pengolahan materi atau informasi menjadi segmen - segmen tulisan sebelum memaknainya.

4. Terapkan proses coding untuk mendeskripsikan oarang - orang, kategori, dan tema yang akan dianalisis

5. Mendeskripsikan tema - tema tersebut kemudian disajikan kembali dalam narasi atau laporan kualitatif.

\section{Hasil Dan Pembahasan}

\section{Efektifitas Fungsi BPD dalam realisasi DD dan ADD}

Berbicara efektifitas fungsi BPD dalam realisasi Dana Desa dan Alokasi Dana Desa berkaitan erat dengan amanah pemerintah pusat dengan mengefektifkan program yang berbasis Desa secara merata dan berkeadilan, sebagaimana UU No 6 tahun 2014 pasal 72 ayat (2). Dana Desa yang bersumber dari APBN dapat digunakan untuk mendanai penyelenggaraan pemerintahan, pelaksanaan pembangunan, pembinaan kemasyarakatan dan pemberdayaan masyarakat ( www.kemenkeu.go.id.). 
Dari peryataan tersebut dapat diketahui jika Peran BPD yag hadir di setiap desa memiliki peran vital, besarnya kucuran DD dan ADD yang dikolala oleh aparatur pemerintah desa setiap tahunnya harus benar - benar tepat sasaran. Dimana tujuan transferan dana dari pemerintah pusat ini tidak hanya untuk pembangunan desa dari segi infrastrukturnya saja. Sehingga makna efektifitas penggunaan DD dan ADD di desa sesuai dengan apa yang telah diusulkan, direncanakan, dan dimplementasikan sesuai kebutuhan masayarakat di desa tersebut.

Kewenangan BPD dalam hal ini terbukti sangat vital, jika hak dan fungsi BPD di desa dapat berjalan dengan optimal maka tentunya fungsi BPD dapar meningkatkan efektifitas penggunaan DD dan ADD dalam mensejahterakan desanya. Karena pada hakikatnya, berbicara efektifitas berarti berkaitan dengan hasil yang dicapai sesuai dibandingkan dengan rencana yang dirumuskan. Jika hasilnya sesuai dengan rencana atau bahkan melebihi dari yang direncanakan maka program berjalan semakin efektif (Handoko, 2000:105).

Adapun hasil penelitian ini berdasarkan kriteria efektifitas menurut Siagian (1978:77), dapat diketahui jika pada point (a) yakni kejelasan tujuan yang ingin dicapai dan point (b) Kejelasan strategi pencapaian tujuan, (c) Proses analisis dan perumusan kebijakan yang mantap, (d) Perencanaan yang matang, (e) Penyusunan program yang tepat (f) Tersedianya sarana dan prasarana kerja, (g) Pelaksanaan yang efektif dan efisien, (h) Sistem pengawasan dan pengendalian yang bersifat mendidik. Dari kedelapan kriteria tersebut, fungsi BPD dalam meningkatkan efektifitas penglolaan DD dan ADD dikatakan optimal pada poin( a) dan poin (e).

Pada poin (a) terkait kejelasan tujuan, di dapat informasi jika hal ini dimaksudkan adalah masing - masing anggota atau karyawana dalam pelaksanaan tugas mencapai sasaran yang terarah dan tujuan organisasi dapat tercapai karena masing - masing anggota telah paham tentang tugas, fungsi dan kewajibannya. Begitu juga dengan kriteria pertama ini, pada umumnya baik ketua dan anggota BPD dari masing - masing desa paham akan kejelasan tujuan dibentuk BPD oleh pemerintah. Sebagaimana pendapat para informan dari hasil wawancara:

"iya tahu tugasnya, termasuk untuk mengumpulkan aspirasi warga, tingkat dusun sampai desa, ikut dalam pembuatan peraturan desa, kami juga setiap hari ikut terlibat dalam menjaga keamanan di desa bergiliran, kita beri penjelasan ke warga terkait usulan yang diterima atau tidak”, (Fatorrohman, Ketua BPD Banuaju Barat. Tanggal: 907-2018).

"iya paham, karena pernah ada sosilissai dari pemerintah kabupaten, semua anggota BPD di kumpulkan. Di beri penejelasan apa tugas dan kewajiban BPD, kalau komplain atauada masalah sarannya kemana begitu dijelaskan semua", (Yibno, Ketua BPD Banuaju Timur. Tanggal: 09-07-2018).

"kenapa ada BPD sebagai rekan kepala desa. Ya..ikut sosialisasi dulu hanya sekali di Sumenep. Yang disampikan ya..itu tugasnya BPD di desa”, (Busahwi Hasan, Ketua BPD Grujugan. Tanggal 12-07-2018). 
"kalau sosialisasi belum pernah tahu, kalau kumpul ya pas diundang semua dengan kepala desa saat musrembangdes,"(H. Mufi, Ketua BPD Desa Jadung. Tanggal: 12-07-2018).

Poin berikutnya yang dirasa optimal dalam menjalankan fungsi BPD yaitu poin (e) yakni penyusunan program yang tepat. Dalam hal ini penyususnan progam yang tepat yang dimaksud adalah bagaimana BPD mampu mengagendaan kegiatan mengumpulkan dan enjaring aspirasi warga dalam rangka melaksanakan rapat musyawarah tingkat dusun, tingkat desa, sampai malaksanakan musrembangdes. Karena agenda kegiatan utama enurut par ainforma dari hasil wawancara, pihak BPD cenderung menadi pihak yang aktif dalam rangka mengumpulkan aspirasi warga yang kemudian aspirasi tersebut disampaikan kepada kepala desa sebagai bentuk perpanajangan tangan dari suara rakyat. Berikut hasil wawancara tersebut:

"Kami pengumpulkan usulan dari masyarakat tingkat dusun mengadakan musdus, setelah terkumpul rapat musdes, baru ke musrembangdes. Setelah itu kami tidak ikut lagi, hanya melakukan pengawasan setelah usulan yang diterima terrealisasi."(Fatorrohman, Ketua BPD Banuaju Barat. Tanggal:15-07-2018).

"Kami yang mengadakan rapat untuk warga mengusulkan, jadi setiap dusun keperluannya apa, misalnya paving, sarana olahraga, nanti kita yang menerima usulan lalu rapat ketingkat desa, lalu ke musrembangdes. kalau anggaran ya sama pendamping desa."(Yibno. Ketua BPD Banuaju timur. Tanggal: 15-07-2018).

"Usulan langsung dari klebun (baca: kepala desa). kalau awal kami yang mengumpulkan usulan dari warga. Nanti mana yang diprioritaskan dapat petunjuk dari klebun (baca: kepala desa)."(H.Mufi, Ketua BPD Jadung. Tanggal:17-07-2018).

"Pembangunan berangkat dari masyarakat, sudah dua periode ini mengumpulkan aspirasi dari dusun - dusun. Turun ke dusun - dusun bersama banyak masyarakat. Tingkat musdes sudah bukan usulan lagi tapi pembacaan yang akan dibacakan sebagai usulan musdes. Menentukan prioritas dari usulan masyarakat di tingkat musrembangdes dari hasil kesepakatan tim 9 yang dibentuk kepala desa.” (Busahwi Hasan, Ketua BPD Grujugan. Tanggal:17-07-2018).

Pada kriteria efektifita lainnya, menunjukkan jika hak dan fungsi BPD dari keseluruh desa tidaklah berjalan optimal. ketidak optimalan ini berakibat pada tidak efektifnya fungsi BPD sebagai rekan kerja kepala desa dalam rangka mengawasi dan mengevaluasi pengelolaan DD dan ADD. Ini terbukti dari hasil wawancara para ketua BPD yang mengjelaskan jika fungsi BPD belumlah maksimal khususnya dalam kegiatan pengewasan kinerja aparatur desa.

"Tidak. Karena list harga atau rumusan biayanya bukan BPD. BPD hanya rancangannya saja, untuk rencana anggaran atau rumusan anggaran dibantu pendamping desa, karena mereka yang tahu harga harga kebutuhan. BPD tidak tahu tentang masalah anggaran. BPD tidak 
memiliki bendahara BPD, bendahara langsung dengan kepala desa."(Fatorrohman, Ketua BPD Banuaju Barat. Tanggal:15-07-2018).

"BPD tidak dilibatkan. Tetapi di perencanaan kita dilibatkan untuk mencari mana yan akan diutamakan." (H.Mufi, Ketua BPD Jadung. Tanggal:17-07-2018).

"Kalau peraturan desa kami tidak dilibatkan, hanya mengumpulkan aspirasi di tingkat musdus dan musdes. Bukannya apa ya bu... saya hanya bicara apa adanya." (Yibno. Ketua BPD Banuaju Timur. Tanggal: 15-07-2018).

"Kepala desa membentuk tim khusus yang beranggotan 9 sampai 11 orang yang tidak genap. Yang bertugas menentukan usulan mana yang akan direalisasikan.bukan lagi wewenang BPD, BPD hanya bertugas mengawasi anggaran dan kegiatan proyek tersebut. misalnya ada proyek pembangunan jalan ada RAP teknis dari pihak luar, yang tahu anggarannya dari pendamping luar/ pendamping desa. Setelah RAP BPD kembali tahu karena ikut tanda tangan dalam RKP, RKP berisi laporan tentang usulan pembangunan yang diterima atau yang di delete (tolak)."(Busahwi Hasan, Ketua BPD Grujugan. Tanggal:17-07-2018).

Berdasarkan data diatas menunjukkan jika kelemahan dari fungsi BPD masih di level perencanaan seperti menjaring aspirasi warga terkait pengelolaan DD dan ADD. Dalam proses pembuatan peraturan desa, penggunaan dan pengawasan anggaran masih sangat lemah dan cenderung tidak terlibat. Ketua dan anggota BPD hanya aktif dilibatkan ketika akan mengadakan rapat musdus, musdes, dan musrembangdes karena harus mengumpulkan aspirasi warga terkait kebutuhan apa yang akan dibangun dari DD. Selebihnya, ditingkat pengawasan anggota BPD hanya terlibat secara formalitas saja karena ikut menandatangani laporan pertanggung jawaban dari realisasi DD dan ADD. Dari situ pihak BPD baru mengetahui jika dari sekian usulan warga yang di ususlkan di tingkat desa, hanya beberapa saja yang dapat direalisasikan oleh kepala desa dengan alasan keterbatasan dana.

\section{Penutup}

BPD hanya berperan pada tingkat rencana dan realisasi namun pada tingkat pengawasan proses belum tergolong maksimal dikarenakan kurang kuatnya hak dan wewenang BPD dalam mendampingi perencanaan, melakukan pengawasan dana mengevaluasi penggunaan anggaran desa yang mana sesungguhnya BPD merupakan mitra kepala desa. Adapun saran yang kami berikan yakni: (a) merumuskan persyaratan atau kualifikasi bagi calon anggota BPD dengan indikator yang jelas. Seperti tingkat pendidikan, pengalaman organisasi, dan penendatangan pakta integritas. (b) pemerintah daerah bekerjasama denga pemerintah desa untuk mensosialisasikan fungsi, hak, wewenang BPD di tingkat masyarakat. Sehingga masyarakat ikut paham apa fungsi BPD dalam struktur pemerintahan desa, selain itu saran berikutnya, (c) adanya penyediaan pusat aduan dari tingkat pusat (kecamatan atau tingkat kabupaten) terkait tugas dan fungsi BPD, dimana pusat aduan tersebut dapat digunakan masyarakat untuk ikut melakukan pengawasan, evaluasi atau memberikan saran terkait 
penyelenggaraan kegiatan pemerintahan desa, misalnya media penampung saran tersebut dapat disalurkan melalui call center atau Sms center.

\section{E. Daftar Pustaka}

Cresweel John W.,2013. "Research Design, Penekatan Kualitatif, Kuantitatif, dan Mixed'. Yogyakarta: Pustaka Pelajar.

Hani Handoko, T., 2000. "Manajemen Personalia dan Sumber Daya Manusia". Yogyakarta:vBPFE UGM.

Hidayat. 1986. Teori Efektivitas Dalam Kinerja Karyawan. Gajah Mada University Press. Yogyakarta.

Lexy Moleong, , 2004. "Metode Penelitian Kualitatif, edisi revisi”, Bandung: PT.Remaja Rosdakarya.

S.P. Sagian.1978. Teori motivasi dan aplikasinya. Jakarta: Bina aksara

\section{Online:}

Haryanto Joko Tri, "Kebijakan Strategis Transfer ke Daerah dan Dana Desa 2016". Dapat dilihat di <http://www.kemenkeu.go.id/Artikel/kebijakan-strategis-transferke-daerah-dan-dana-desa-2016>, diakses pada 15 Februari 2015.

Masawah. "kebijakan dan anggaran dana desa". dapat dilihat di $<$ http://www.masawah.desa.id/2015/08/kebijakan-dananggaran-dana-desa-dalam.html $>$ diakses pada, 15 februari 2017.

Masawah.desa."kebijakan dan anggaran dana desa". dapat diakses dalam $<$ http://www.masawah.desa.id/2015/08/kebijakan-dananggaran-dana-desa-dalam.html>, diakses pada 15 februari 2017.

Setkab. "dana desa pemerintaha jokowi wujudkan kedaulatan desa". dapat dilihat di <http://setkab.go.id/dana-desa-pemerintahan-jokowiwujudkan-kedaulatan-desa/> diakses pada 15 februari 2017.

Timesindonesia., 2016. "Kontrol DD dan ADD, DPRD Sumenep Lakukan Sejumlah Sidak"., dapat dilihat pada $<$ http://m.timesindonesia.co.id/read/132606/20160913/160234/k ontrol-dd-dan-add-dprd-sumenep-lakukan-sejumlah-sidak/>, diakses pada 16 februari 2017

PERMENDAGRI No. 110 Tahun 2016 Tentang Badan Permusyawaratan Desa (BPD. Diakses 5 oktober 2018, dalam situs www.permendagri.go.id.

Kementerian Keuangan Republik Indonesia. 2017. Buku Pintar Dana Desa. Source: $\quad$ Diakses 5 oktober 2018, dalam situs www.kemenkeu.go.id. 